\title{
ANALISIS UKURAN PERUSAHAAN, FREE CASH FLOW(FCF) DAN KEBIJAKAN HUTANG TERHADAP KINERJA KEUANGAN PADA PERUSAHAAN MANUFAKTUR YANG TERDAFTAR DI BURSA EFEK INDONESIA
}

\author{
Bhakti Helvi Rambe \\ bhaktihelvirambe@gmail.com \\ Prodi Akuntansi Universitas Labuhan Batu
}

\begin{abstract}
The purpose of this study was to analyze the Free Cash Flow (FCF) Firm Size and the Debt to Equity Ratio on Financial Performance of Manufacturing Companies on the Indonesia Stock Exchange. This research is causal. The data taken as this research are Manufacturing Companies listed on the Indonesia Stock Exchange in 2017-2018. The population in the study was 146 companies, with a sample of 30 companies using the purposive sampling method, so that the number of observations was 60 units of observation. The data analysis method in this research is multiple linear regression. $R$ Square Testing Results of 0.162 means that the independent variable is X1Firm Size x2 Free Cash Flow (FCF), x3 Debt to Equty Ratio simultaneously affects Financial Performance by $16.2 \%$ and the remaining $83.8 \%$ is influenced by other factors. Research Results Partially understood that the Firm Size variable has no negative effect and is not significant on Financial Performance. According to the data in table 5. Results of the statistical equation test that the value of Sig. Firm Size variable x1 0.872> 0.05 does not affect and is not significant to the dependent variable Y Financial Performance then the hypothesis is rejected. The results of the study are partially understood that the Free Cash Flow (FCF) variable has a positive and significant effect on financial performance. According to the data in table 5. Results of the statistical equation test that the value of Sig. variable Free Cash Flow (FCF) x2 $0.043<0.05$ significant effect on the dependent variable $Y$ Financial Performance. Then the variable Free Cash Flow (FCF) hypothesis has a positive effect on the Financial Performance of Manufacturing Companies in the Indonesia Stock Exchange. The research results are partially known that the Debt to Equity Ratio variable has a positive and significant effect on Financial Performance. Sig value. Debt to Equity Ratio Variable $x 30.018<0.05$ has a significant effect on the dependent variable Y Financial Performance of manufacturing companies on the Indonesia Stock Exchange. Then the hypothesis of Debt to Equity Ratio Variables has a positive effect on the Financial Performance of Manufacturing Companies on the Indonesia Stock Exchange. It is simultaneously significant. Where the probability value (Sig.) $0.018<0.05$, the influence of the free variable consists of the variable Company Size x1, Free Cash Flow (FCF) variable x2, Debt to Equity Ratio Variable $x 3$ Against the Bound Variable Financial Performance variable Y in Manufacturing Companies listed on Indonesia stock exchange.
\end{abstract}

Keywords: Firm Size, Free Cash Flow (FCF) Debt to Equity Ratio (DER), Financial Performance, multiple linear regression.

\section{I.Pendahuluan}

Kinerja keuangan merupakan gambaran mengenai keadaan keuangan perusahaan dalam jangka waktu tertentu yang merupakan hasil dari banyak keputusan individual yang dibuat secara terus menerus oleh pihak manajemen (Sucipto, 2003:1). Informasi mengenai kinerja 
keuangan akan menjadi sangat penting bagi investor sebagai alat pengambilan keputusan berinvestasi.

Perusahaan pasti mempunyai target dalam memperoleh keuntungan atau profit agar stackholder dan investor memperoleh keuntungan maupun manajemen perusahaan. Rasa semangat bahwa perusahaan tersebut sehat dan dapat dipercaya. Perusahaan manufaktur bergerak bidang badan usaha yang mengoperasikan mesin, peralatan dan tenaga kerja dalam suatu medium proses untuk mengubah bahan- bahan mentah menjadi barang jadi yang memiliki nilai jual. Perusahaan yang baik mesti bagus dalam melaporkan kinerja keuangannya dimana laporan keuangan setiap perusahaan dilaporkan secara berkala, dengan laporan keuangan yang selalu dilaporkan merupakan akhir dari proses akuntansi dengan tujuan menjabarkan kondisi akhir perusahaan. Kinerja kuangan merupakan salah satu indikator dapat digunakan seorang investor untuk menilai sebuah perusahaan manufaktur layak atau tidak untuk menginvestasikan dana.(Fatimah, Mardani, \& Wahono, 2017).

Kinerja keuangan merupakan gambaran mengenai keadaan keuangan perusahaan dalam jangka waktu tertentu yang merupakan hasil dari banyak keputusan individual yang dibuat secara terus menerus oleh pihak manajemen Informasi mengenai kinerja keuangan akan menjadi sangat penting bagi investor sebagai alat pengambilan keputusan berinvestasi.

Hubungan antara pemegang saham atau investor dan manajer dapat mengarah pada kondisi asimetri informasi karena manajer berada pada posisi yang memiliki informasi yang lebih banyak tentang perusahaan dibandingkan dengan pemegang saham. Berdasarkan asumsi bahwa individu-individu bertindak untuk memaksimalkan kepentingan diri sendiri, maka dengan informasi asimetri yang dimilikinya akan mendorong manajer untuk menyembunyikan beberapa informasi yang tidak diketahui pemegang saham. Kondisi tersebut membuat manajer dapat mempengaruhi angka-angka akuntansi yang di sajikan dalam laporan keuangan dengan cara melakukan manajemen laba.

Setiap perusahaan pasti mempunyai aset berharga dengan nilai total aset perusahaan yang baik akan mempengaruhi ukuran perusahaan. Pada umumnya perusahaan yang besar memiliki aset yang baik dibandingkan perusahaan kecil dimana memiliki aset lebih kecil. Ukuran perusahaan yang memiliki nilai aset yang besar mengambarkan perusahaan tersebut sedang berkembang dan mengalami pertumbuhan yang baik sehingga investor lebih optimis untuk menginvenstasikan kepada perusahaan tersebut.(Dahar, Yanti, \& Rahmi, 2019). Ukuran perusahaan merupakan faktor penting dalam menentukan kinerja keuangan perusahaan. Perusahaan yang memiliki ukuran perusahaan yang lebih besar mempunyai pengaruh terhadap profitabilitas perusahaan. Hal ini dikarenakan perusahaan yang lebih besar memiliki beberapa keuntungan kompetitif, antara lain kekuatan pasar dimana perusahaan besar dapat menetapkan harga yang tinggi untuk produknya, adanya skala ekonomi yang berdampak pada penghematan biaya karena. Hal ini akan berdampak pada peningkatan profitabilitas dari perusahaan. Terdapat dua pandangan tentang bentuk ukuran perusahaan terhadap manajemen laba. Pandangan pertama, ukuran perusahaan yang kecil dianggap lebih banyak melakukan praktik manajemen laba daripada perusahaan besar.

Dalam mengembangkan dan menjalankan perusahaan baik berupa kegiatan operasional serta modal kerja dapat berjalan lancar. Perusahaan manufaktur hendaknya mempunyai arus kas bebas (FCF) yang benar benar tersedia dimana sisa kas yang dimiliki perusahaan sebagai cadangan dana ketika perusahaan dalam keadaan urgent bisa digunakan.(Setiawati, Mujiyati, \& Rosit, 2019). Perusahaan harus bijak dalam mengelola dana perusahaan apalagi pendanaan tersebut diperoleh dari sumber eksternal bukan dari dana yang dimiliki perusahaan. Dalam penggunaan hutang sangat sensitif pengaruhnya baik pada kinerja keuangan yang harus dilaporkan secara berkala, sehingga ukuran perusahaan berpengaruh dalam memiliki nilai aset yang baik kapan hutang harus dibayarkan kembali serta perusahaan harus memastikan 
pembagian keuntungan atau profit kepada investor yang telah menginvestasikan pada perusahaan tersebut(Setiono, Susetyo, \& Mubarok, 2017).

\section{Telaah Literatur Dan Pengembangan Hipotesis Teori tentang Ukuran Perusahaan}

Ukuran perusahaan adalah suatu skala atau nilai dimana perusahaan dapat diklasifikasikan besar kecilnya berdasarkan total aktiva, log size, nilai saham, dan lain sebagainya. Ukuran perusahaan dapat dinyatakan dalam total aktiva, penjualan dan kapitalisasi pasar. Jika semakin besar total aktiva, penjualan dan kapitalisasi pasarnya maka semakin besar pula ukuran perusahaan tersebut. Ketiga variabel tersebut dapat digunakan untuk menentukan ukuran perusahaan karena dapat mewakili seberapa besar ukuran perusahaan tersebut, misal semakin besar aktiva maka akan semakin banyak modal yang ditanam, semakin banyak penjualan maka semakin banyak perputaran uang dan semakin besar kapitalisasi pasar maka akan semakin besar pula perusahaan itu dikenal dalam masyarakat. Ukuran perusahaan dapat dilakukan penilaian atau pengukuran dapat dilihat pada besar atau kecilnya perusahaan dengan mengamati total aset atau total penjualan yang dimiliki oleh perusahaan tersebut(Azhari \& Nuryatno, 2019).

Menurut Halim dan Sarwoko Ukuran perusahaan merupakan besar kecilnya perusahaan, baik dari segi jumlah aktiva maupun dari segi tingkat penjualan, akan sangat mempengaruhi besarnya modal kerja.(Mudjijah, Khalid, \& Astuti, 2019).

\section{Teori tentang Free Cash Flow (FCF)}

Menurut Murhadi Arus Kas Segar (Free Cash Flow) adalah kas yang tersedia di perusahaan tersedia di perusahaan yang dapat digunakan untuk berbagai aktivitas(Basir \& Muslih, 2019). Arus Kas Segar (Free Cash Flow) memperhatikan secara khusus pada kas yang dihasilkan dari aktivitas operasi setelah digunakan untuk kebutuhan reinvestasi.(Fadilla \& Aryani, 2019).

Menurut Ross et al. arus kas bebas sebagai kas perusahaan yang bisa di liquidasi dan didistribusikan Untuk kreditor atau pemegang saham berinvestasi dalam modal atau aset tetap, setelah perusahaan membayar semua investasi dan modal kerja dari kegiatan manajemen untuk mengembangkan bisnisnya, dapat disimpulkan bahwa arus kas bebas adalah sisa kas perusahaan(Sulastri, Puspa, \& Fauziati, 2016).

\section{Teori tentang Kebijakan Hutang}

Menurut Riyanto Kebijakan hutang adalah kebijakan yang diambil pihak manajemen dalam rangka memperoleh sumber daya pembiayaan bagi perusahaan sehingga dapat digunakan untuk membiayai aktivitas operasional perusahaan(Somantri \& Sukardi, 2019).

Menurut munawir hutang adalah semua kewajiban keuangan perusahaan atau modal kepada pihak lain yang belum terpenuhi, dimana hutang ini merupakan sumber dana atau modal perusahaan yang berasal dari kreditor(Sihotang \& Saragih, 2017).

hutang adalah kewajiban suatu perusahaan yang timbul dari transaksi pada waktu yang lalu dan harus dibayar dengan kas, barang atau jasa, di waktu yang akan datang. Kewajiban dikelompokkan menjadi kewajiban lancar dan kewajiban jangka panjang.(Lestari, 2018)

\section{Teori tentang Kinerja Keuangan}

Kinerja keuangan merupakan suatu gambaran tentang kondisi keuangan suatu perusahaan yang dianalisis dengan alat-alat analisis keuangan, sehingga dapat diketahui mengenai baik buruknya keadaan keuangan suatu perusahaan yang mencerminkan prestasi kerja dalam periode tertentu.. Berdasarkan penelitian terdahulu, terdapat beberapa pengukuran yang dapat digunakan untuk menilai kinerja keuangan perusahaan yaitu ROA dan ROE. 
Menurut Brigham dan Houston Return on Assets adalah rasio profitabilitas perusahaan yang diukur dengan membandingkan laba bersih dengan total aset perusahaan, untuk mengukur efektifitas penggunaan aset perusahaan. Menurut Sartono Return On Asset mengukur kemampuan perusahaan memperoleh laba dengan menggunakan asset yang dimiliki. Jika nilai return on asset semakin tinggi maka semakin tinggi juga laba yang dihasilkan suatu perusahaan.(Mudjijah et al., 2019).

Kinerja keuangan gambaran suatu kondisi keuangan perusahaan pada periode tertentu, baik menyangkut aspek penghimpun dana maupun penyaluran dana yang biasanya diukur dengan indikator kecukupan modal, profitabilitas, dan likuiditas(Fatimah et al., 2017).

\section{Teori tentang Regresi linier berganda}

Regresi linier adalah metode statistika yang digunakan untuk membentuk model hubungan antara variabel terikat (dependen; respon; Y) dengan satu atau lebih variabel bebas (independen, prediktor, X). Apabila banyaknya variabel bebas hanya ada satu, disebut sebagai regresi linier sederhana, sedangkan apabila terdapat lebih dari 1 variabel bebas, disebut sebagai regresi linier berganda. Analisis regresi setidak-tidaknya memiliki 3 kegunaan, yaitu untuk tujuan deskripsi dari fenomena data atau kasus yang sedang diteliti, untuk tujuan kontrol, serta untuk tujuan prediksi. Regresi mampu mendeskripsikan fenomena data melalui terbentuknya suatu model hubungan yang bersifatnya numerik. Regresi juga dapat digunakan untuk melakukan pengendalian (kontrol) terhadap suatu kasus atau hal-hal yang sedang diamati melalui penggunaan model regresi yang diperoleh. Selain itu, model regresi juga dapat dimanfaatkan untuk melakukan prediksi untuk variabel terikat. Contoh model regresi:

$$
\mathrm{Y}=0.201+0.212 * \mathrm{X}+\mathrm{e}
$$

Angka 0.201 merupakan intersep, 0.212 merupakan slope, sedangkan e merupakan error.Error bukanlah berarti sesuatu yang rusak,

hancur atau kacau. Pengertian error di dalam konsep statistika berbeda dengan pengertian error yang selama ini dipakai di dalam kehidupan sehari-hari. Di dalam konsep regresi linier, error adalah

semua hal yang mungkin mempengaruhi variabel terikat $\mathrm{Y}$, yang tidak diamati oleh peneliti.(Kurniawan, 2008).

\section{Teori Purposive Sampling}

Purposive sampling adalah salah satu teknik sampling non random sampling dimana peneliti menentukan pengambilan sampel dengan cara menetapkan ciri-ciri khusus yang sesuai dengan tujuan penelitian sehingga diharapkan dapat menjawab permasalahan penelitian. Berdasarkan penjelasan purposive sampling tersebut, ada dua hal yang sangat penting dalam menggunakan teknik_sampling tersebut, yaitu non random sampling dan menetapkan ciri khusus sesuai tujuan penelitian oleh peneliti itu sendiri. Menurut Arikunto Purposive sampling adalah teknik mengambil sampel dengan tidak berdasarkan random, daerah atau strata, melainkan berdasarkan atas adanya pertimbangan yang berfokus pada tujuan tertentu. Sedangkan Menurut Sugiyono pengertiannya adalah teknik untuk menentukan sampel penelitian dengan beberapa pertimbangan tertentu yang bertujuan agar data yang diperoleh nantinya bisa lebih representatif.(Muharromah, Amin, \& Mawardi, 2018)

Berdasarkan teoritis dan kajian peneliti yang dilakukan yang terdahulu, dengan kerangka konsep dan hipotesis sebagai berikut : 


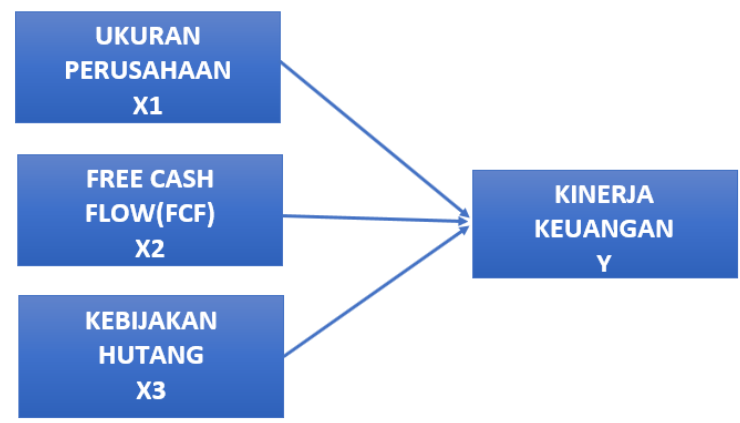

Gambar1. Kerangka Konseptual

1. Variabel Ukuran Perusahaan berpengaruh positif terhadap Kinerja Keuangan Pada Perusahaaan Manufaktur di Bursa Efek Indonesia baik secara simultan dan parsial.

2. Variabel Free Cash Flow (FCF) berpengaruh positif terhadap Kinerja Keuangan Pada Perusahaaan Manufaktur di Bursa Efek Indonesia baik secara simultan dan parsial.

3. Variabel Kebijakan Hutang berpengaruh positif terhadap Kinerja Keuangan Pada Perusahaaan Manufaktur di Bursa Efek Indonesia Baik secara simultan dan parsial.

4. Variabel Ukuran Perusahaan, Free Cash Flow (FCF), dan Kebijakan Hutang berpengaruh positif terhadap Kinerja Keuangan Pada Perusahaaan Manufaktur di Bursa Efek Indonesia Baik Secara simultan dan parsial.

\section{Metode Penelitian}

Penelitian ini merupakan penelitian kausal.

Data yang diambil sebagai penelitian ini adalah Perusahaan Manufaktur yang terdaftar di Bursa Efek Indonesia dengan Laman akses https://www.idx.co.id/. Populasi dalam penelitian 30 perusahaan, dengan sampel 30 perusahaan menggunakan metode purposive sampling, sehingga jumlah observasi 60 unit observasi. Metode analisis data dalam penelitian ini merupakan regresi linier berganda.

Tabel 1. Definisi Operasional dan Pengukuran Variabel

\begin{tabular}{|c|c|c|c|}
\hline Variabel & Definisi Variabel & Parameter & Skala \\
\hline $\begin{array}{c}\text { Kinerja Keuangan } \\
\text { (Y) }\end{array}$ & $\begin{array}{l}\text { Penentuan ukuran-ukuran } \\
\text { tertentu yang dapat } \\
\text { mengukur keberhasilan } \\
\text { suatu perusahaan dalam } \\
\text { menghasilkan laba pada } \\
\text { suatu periode tertentu }\end{array}$ & $R O A=\frac{\text { Laba Bersih }}{\text { Total Aset }}$ & Rasio \\
\hline $\begin{array}{l}\text { Ukuran Perusahaan } \\
\text { (X1) }\end{array}$ & $\begin{array}{l}\text { Penjumlahan dari aktiva } \\
\text { lancar dan aktiva tetap yang } \\
\text { merupakan } \\
\text { perusahaansecara } \\
\text { keseluruhan. }\end{array}$ & Ln (Total Aset) & Rasio \\
\hline $\begin{array}{l}\text { Free Cash Flow } \\
\text { (X2) }\end{array}$ & 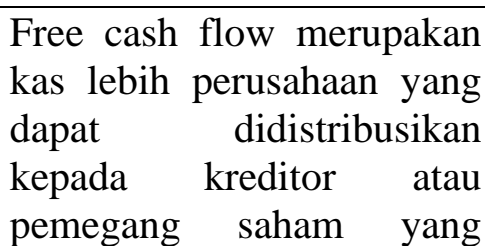 & 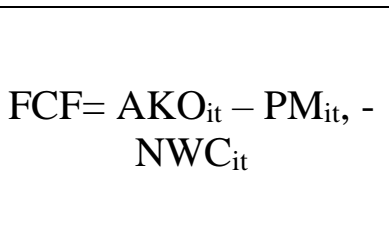 & Rasio \\
\hline
\end{tabular}




\begin{tabular}{|c|l|l|l|}
\hline & $\begin{array}{l}\text { tidak diperlukan lagi untuk } \\
\text { modal kerja atau investasi } \\
\text { pada asset tetap }\end{array}$ & \\
\hline $\begin{array}{c}\text { Kebijkan } \\
\text { Hutang(DER) } \\
(\mathrm{X} 3)\end{array}$ & $\begin{array}{l}\text { Perbandingan antara total } \\
\text { hutang dan total equitas } \\
\text { yang digunakan sebagai } \\
\text { sumber pendanaan usaha } \\
\text { yang menyangkut keputusan } \\
\text { pendanaan. }\end{array}$ & $\begin{array}{c}\text { DER } \\
\text { Total Debt }\end{array}$ & Rasio \\
\hline
\end{tabular}

\section{Hasil Penelitian Dan Pembahasan \\ 1) Deskripsi Variabel Penelitian \\ Tabel 2. Statistik Deskriptif}

Descriptive Statistics

\begin{tabular}{|l|r|r|r|r|r|}
\hline & \multicolumn{1}{|c|}{ N } & \multicolumn{1}{|c|}{ Min } & \multicolumn{1}{c|}{ Max } & \multicolumn{1}{c|}{ Mean } & \multicolumn{1}{c|}{ Std. Deviation } \\
\hline Ukuran Perusahaan & 60 & 24.42 & 31.83 & 28.3482 & 1.81013 \\
FCF & 60 & -7.66 & 8.71 & 3.1358 & 2.94330 \\
Kebijakan Hutang & 60 & .01 & 2.65 & .5950 & .52040 \\
Kinerja Keuangan & 60 & .02 & 1.36 & .2517 & .35364 \\
Valid N (listwise) & 60 & & & & \\
\hline
\end{tabular}

\section{Sumber data diolah peneliti 2019}

Pada Tabel 2. Statistik Deskritif meliputi data yang telah diolah dengan metode statistik, data tersebut sebanyak 59 (N) data dengan Variabel bebas Ukuran Perusahaan X1, Fresh Cash Flow (FCF) X2, Kebijakan Hutang X3 dan variabel terikat Kinerja Keuangan Y masing-masing data tersaji dari nilai min, max, mean serta Std.Deviation.

2) Pengujian Asumsi Klasik

Tabel 3. Uji Normalitas

One-Sample Kolmogorov-Smirnov Test

\begin{tabular}{|ll|r|}
\hline & & \multicolumn{1}{|c|}{ Unstandardized Residual } \\
\hline $\mathrm{N}$ & & 60 \\
Normal Parameters & Mean & $0 \mathrm{E}-7$ \\
& Std. Deviation & .32344536 \\
& Absolute & .247 \\
Most Extreme Differences & Positive & .247 \\
& Negative & -.106 \\
Kolmogorov-Smirnov Z & & 1.910 \\
Asymp. Sig. (2-tailed) & & .001 \\
\hline
\end{tabular}

a. Test distribution is Normal.

b. Calculated from data.

\section{Sumber data diolah peneliti 2019}

Pada tabel 3. Uji Normalitas diatas maka hasil uji normalitas data residual terdistribusi secara normal 


\begin{tabular}{|c|c|c|c|c|}
\hline & & \multicolumn{2}{|c|}{ Collinearity Statistics } & \multirow{2}{*}{ Keterangan } \\
\hline & & Tolerance & VIF & \\
\hline \multirow{4}{*}{1} & (Constant) & & & \\
\hline & Ukuran Perusahaan & .974 & 1.027 & Tidak teriadi mutikolinieritas \\
\hline & $\mathrm{FCF}$ & .995 & 1.005 & Tidak terjadi multikolinieritas \\
\hline & Kebijakan Hutang & .971 & 1.030 & Tidak terjadi multikolinimeritas \\
\hline
\end{tabular}

a. Dependent Variabel: Kinerja Kevangan

Sumber data diolah peneliti 2019

\section{Gambar 2. Hasil Pengujian Uji Multikolinieritas}

Pada gambar 2. Hasil Pengujian Uji Multikolineritas bahwasanya data yang diolah menghasilkan Uji multikolinieritas dengan nilai tolerance untuk semua variabel berada di atas 0.1 dan nilai VIF berada di bawah 10, sehingga dapat disimpulkan bahwa tidak ada korelasi di antara variabel bebas yang digunakan atau tidak terjadi masalah dalam uji multikolinieritas.

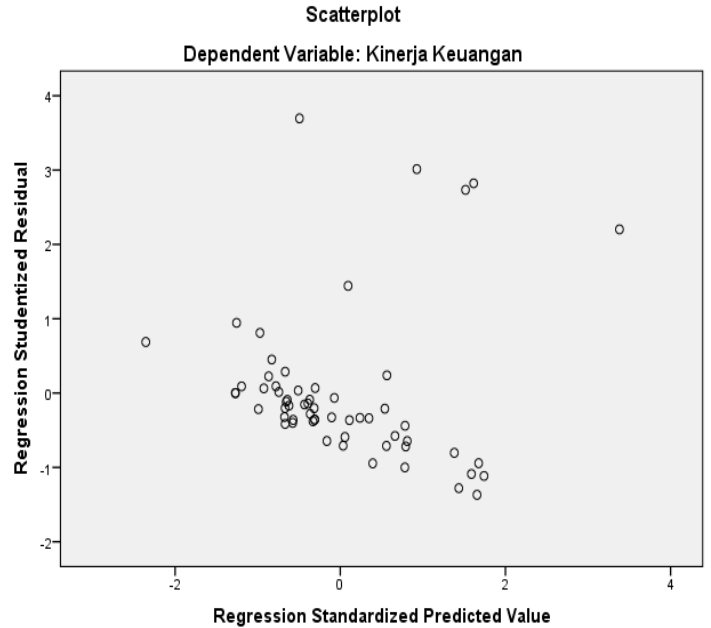

Gambar 3. Grafik Scatterplot Uji Heteroskedastisitas

Berdasarkan hasil uji heteroskedastisitas diketahui bahwa titik-titik tidak ada yang menumpuk dan menyebar di atas dan di bawah angka 0 pada sumbu Y, sehingga dapat disimpulkan data tidak terjadi masalah dalam uji heteroskedastisitas.

\begin{tabular}{|l|r|}
\hline \multicolumn{2}{|c}{ Runs Test } \\
\begin{tabular}{|l|r|}
\hline \multicolumn{1}{|c}{ Unstandardized } \\
Residual
\end{tabular} \\
\hline Test Value & -.06753 \\
Cases < Test Value & 30 \\
Cases >= Test Value & 30 \\
Total Cases & 60 \\
Number of Runs & 29 \\
Z & -.521 \\
Asymp. Sig. (2-tailed) & .602 \\
\hline a. Median
\end{tabular}

\section{Gambar 4. Hasil Pengujian Autokorelasi}

Pada gambar 4. Hasil Pengujian Auto kolerasi bahwasnya data yang diiolahmmenghasilkan nilai Asymp.Sig. (2-tailed) yang diperoleh berada di atas 0.05 (0.602), sehingga dapat disimpulkan bahwa model regresi tidak terjadi masalah dalam uji autokorelasi. 


\section{3) Hasil Uji Simultan (Uji F)}

Tabel 4. Hasil Uji Statistikal F

\begin{tabular}{|c|c|c|c|c|c|}
\hline \multicolumn{6}{|c|}{ ANOVA $^{\mathrm{a}}$} \\
\hline Model & $\begin{array}{c}\text { Sum of } \\
\text { Square } \\
\text { s }\end{array}$ & $\mathrm{df}$ & $\begin{array}{c}\text { Mean } \\
\text { Squar } \\
\text { e }\end{array}$ & $\mathrm{F}$ & Sig. \\
\hline $\begin{array}{l}\text { Regressi } \\
\text { on }\end{array}$ & 1.206 & 3 & .402 & $\begin{array}{r}3.64 \\
8\end{array}$ & $\begin{array}{r}.01 \\
8^{b}\end{array}$ \\
\hline${ }^{1}$ Residual & 6.172 & 56 & .110 & & \\
\hline Total & 7.379 & 59 & & & \\
\hline
\end{tabular}

a. Dependent Variable: Kinerja Keuangan

b. Predictors: (Constant), Kebijakan

Hutang, FCF, Ukuran Perusahaan

\section{Sumber data diolah peneliti 2019}

Pada tabel 4. Hasil Uji Statistik F dapat dipahami bahwa nilai probabilitas (Sig) 0,000. Karena nilai probabilitas (Sig.) 0,018 < 0,05, maka pengaruh variabel bebas terdiri dari variabel Ukuran Perusahaan x1, variabel Free Cash Flow (FCF) x2, Variabel Kebijakan Hutang x3 Terhadap Variabel Terikat variabel Kinerja Keuangan Y pada Perusahaan Manufaktur yang terdaftar pada Bursa Efek Indonesia secara simultan signifikan.

\section{Hasil Uji Parsial (Uji t)}

Tabel 5. Hasil Uji Statistikalt Persamaan

Coefficients $^{\mathrm{a}}$

\begin{tabular}{|c|c|c|c|c|c|}
\hline \multirow[t]{2}{*}{ Model } & \multicolumn{2}{|c|}{$\begin{array}{l}\text { Unstandardized } \\
\text { Coefficients }\end{array}$} & $\begin{array}{c}\text { Standardized } \\
\text { Coefficients }\end{array}$ & \multirow[t]{2}{*}{$\mathrm{t}$} & \multirow[t]{2}{*}{ Sig. } \\
\hline & $\mathrm{B}$ & Std. Error & Beta & & \\
\hline (Constant) & .145 & .684 & & .212 & .833 \\
\hline Ukuran & -.004 & .024 & -.020 & -.162 & .872 \\
\hline $\mathrm{FCF}$ & .030 & .015 & .253 & 2.068 & .043 \\
\hline Kebijakan Hutang & .205 & .084 & .302 & 2.434 & .018 \\
\hline
\end{tabular}

a. Dependent Variable: Kinerja Keuangan

Sumber data diolah peneliti 2019

Pada tabel 5.Hasil Uji statitikal persamaan (Uji T) menghasilkan persamaan regresi yaitu: $\mathrm{Y}=$ $0.145-0.004 \times 1+0.030 \times 2+0.205 \times 3+e_{2}$ maka nilai Sig. variabel Ukuran Perusahaan $\times 10,872$ $>0,05$ tidak mempengaruhi dan tidak signifikan terhadap variabel terikat Y Kinerja Keuangan. Nilai Sig. variabel Free Cash Flow (FCF) x2 0,043 < 0,05 berpengaruh signfikan terhadap variabel terikat Y Kinerja Keuangan. Dan nilai Sig. Variabel Kebijakan Hutang x3 0,018 < 0,05 berpengaruh signifikan terhadap varibel terikat Y Kinerja Keuangan pada perusahaan manufaktur di Bursa Efek Indonesia.

4) Koefisien Determinasi

Tabel 6. Koefisien Determinasi

Model Summary

\begin{tabular}{|l|r|r|r|r|}
\hline Model & \multicolumn{1}{|c|}{ R } & R Square & Adjusted R Square & $\begin{array}{c}\text { Std. Error of the } \\
\text { Estimate }\end{array}$ \\
\hline 1 & $.403^{\mathrm{a}}$ & .162 & .117 & .33462 \\
\hline
\end{tabular}


a. Predictors: (Constant), Kebijakan Hutang X3, FCF X2, Ukuran Perusahaan X1

b. $\quad$ Dependent Variable: Kinerja Keuangan (Y)

\section{Sumber data diolah peneliti 2019}

Pada Tabel 6. Koefisien Determinasi dapat dipahami bahwa nilai yang terjadi pada koefisien determinasi untuk persamaan bernilai $\mathrm{R}$ Square $=0.162$ berarti variabel bebas yaitu $\mathrm{x} 1$ Ukuran Perusahaan x2 Free Cash Flow (FCF), x3 Kebijakan Hutang secara simultan mempengaruhi Kinerja Keuangan sebasar 16,2\% dan sisanya $83.8 \%$ dipengaruhi faktor-faktor lain.

\section{Pembahasan Hasil Penelitian}

\section{Pengaruh Variabel Ukuran Perusahaan Terhadap Variabel Kinerja Keuangan.}

Berdasarkan hasil penelitian secara parsial dimengerti bahwa variabel Ukuran Perusahaan tidak berpengaruh negatif serta tidak signifikan terhadap Kinerja Keuangan. Sesuai data pada tabel 5. Hasil Uji statistikal persamaan bahwa nilai Sig. variabel Ukuran Perusahaan x1 0,872 $>0,05$ tidak mempengaruhi dan tidak signifikan terhadap variabel terikat Y Kinerja Keuangan maka hipotesis Variabel Ukuran Perusahaan berpengaruh positif terhadap Kinerja Keuangan Pada Perusahaaan Manufaktur di Bursa Efek Indonesia ditolak. Hal ini ukuran perusahaan yang besar belum tentu menghasilkan kinerja keuangan perusahaan yang lebih baik. Semakin besar asset yang dimiliki perusahaan, semakin besar pula masalah kinerja keuangan yang dihadapi. Penelitian ini sejalan dengan sulastri menyatakan bahwa ukuran perusahaan tidak berpengaruh signifikan terhadap kinerja keuangan perusahaan.(Sulastri et al., 2016)

\section{Pengaruh Variabel Free Cash Flow (FCF) Terhadap Variabel Kinerja Keuangan.}

Berdasarkan hasil penelitian secara parsial dimengerti bahwa variabel Free Cash Flow (FCF) berpegaruh positif serta signifikan terhadap Kinerja Keuangan. Sesuai data pada tabel 5. Hasil Uji statistikal persamaan bahwa nilai Sig. variabel Free Cash Flow (FCF) x2 0,043 < 0,05 berpengaruh signfikan terhadap variabel terikat Y Kinerja Keuangan. Maka hipotesis Variabel Free Cash Flow(FCF) berpengaruh positif terhadap Kinerja Keuangan Pada Perusahaaan Manufaktur di Bursa Efek Indonesia diterima. Hal ini disebabkan oleh sisa kas perusahaan oleh manajer tidak dibagikan kepada para memegang saham sebagai dividen. Sisa kas perusahaan oleh manajer digunakan untuk berinvestasi pada struktur modal atau yang lainnya. Ada kemungkinan free cash flow dipergunakan pada struktur modal atau yang lainnya sehingga menyebabkan kinerja keuangan perusahaan mengalami peningkatan karena adanya penambahan modal pada struktur modal berakibat pada adanya inovasi baru pada produk yang dijualnya. Penelitian ini sejalan dengan penelitian yang pernah dilakukan oleh Syamsudin (Syamsudin, Afifudin, \& Junaidi, 2019).

\section{Pengaruh Variabel Kebijakan Hutang Terhadap Variabel Kinerja Keuangan.}

Berdasarkan hasil penelitian secara parsial diketahui bahwa variabel Kebijakan Hutang berpengaruh positif dan signifikan terhadap Kinerja Keuangan. nilai Sig. Variabel Kebijakan Hutang x3 0,018<0,05 berpengaruh signifikan terhadap varibel terikat Y Kinerja Keuangan pada perusahaan manufaktur di Bursa Efek Indonesia. Maka hipotesis Variabel Kebijakan Hutang berpengaruh positif terhadap Kinerja Keuangan Pada Perusahaaan Manufaktur di Bursa Efek Indonesia diterima. Hal ini dikarenakan pendanaan melalui hutang akan meningkatkan kinerja keuangan perusahaan dimana perusahaan yang memiliki hutang akan membayar bunga pinjaman yang dapat mengurangi penghasilan kena pajak yang dapat memberikan manfaat bagi pemegang saham. Penelitian ini sejalan dengan penelitian yang pernah dilakukan oleh Lestari(Lestari, 2018) 


\section{Kesimpulan}

Berdasarkan hasil penelitian serta pembahasan hasil penelitian yang telah dilakukan, maka dapat diambil kesimpulan sebagai berikut:

a) Hasil Pengujian R Square sebesar 0,162 berarti variabel bebas yaitu x1 Ukuran Perusahaan x2 Free Cash Flow (FCF), x3 Kebijakan Hutang secara simultan mempengaruhi Kinerja Keuangan sebasar 16,2\% dan sisanya $83.8 \%$ dipengaruhi faktor-faktor lain.

b) Hasil Penelitian Secara parsial dimengerti bahwa variabel Ukuran Perusahaan tidak berpengaruh negatif serta tidak signifikan terhadap Kinerja Keuangan. Sesuai data pada tabel 5. Hasil Uji statistikal persamaan bahwa nilai Sig. variabel Ukuran Perusahaan x1 $0,872>0,05$ tidak mempengaruhi dan tidak signifikan terhadap variabel terikat Y Kinerja Keuangan maka hipotesis ditolak.

c) Hasil penelitian secara parsial dimengerti bahwa variabel Free Cash Flow (FCF) berpegaruh positif serta signifikan terhadap Kinerja Keuangan. Sesuai data pada tabel 5. Hasil Uji statistikal persamaan bahwa nilai Sig. variabel Free Cash Flow (FCF) x2 0,043 < 0,05 berpengaruh signfikan terhadap variabel terikat Y Kinerja Keuangan. Maka hipotesis Variabel Free Cash Flow(FCF) berpengaruh positif terhadap Kinerja Keuangan Pada Perusahaaan Manufaktur di Bursa Efek Indonesia diterima

d) Hasil penelitian secara parsial diketahui bahwa variabel Kebijakan Hutang berpengaruh positif dan signifikan terhadap Kinerja Keuangan. nilai Sig. Variabel Kebijakan Hutang x3 $0,018<0,05$ berpengaruh signifikan terhadap varibel terikat Y Kinerja Keuangan pada perusahaan manufaktur di Bursa Efek Indonesia. Maka hipotesis Variabel Kebijakan Hutang berpengaruh positif terhadap Kinerja Keuangan Pada Perusahaaan Manufaktur di Bursa Efek Indonesia diterima.

e) Secara simultan signifikan. Dimana nilai probabilitas (Sig.) 0,018 $<0,05$, maka pengaruh variabel bebass terdiri dari variabel Ukuran Perusahaan x1, variabel Free Cash Flow (FCF) x2, Variabel Kebijakan Hutang x3 Terhadap Variabel Terikat variabel Kinerja Keuangan Y pada Perusahaan Manufaktur yang terdaftar pada Bursa Efek Indonesia.

\section{DAFTAR PUSTAKA}

Azhari, F., \& Nuryatno, M. (2019). PERAN OPINI AUDIT SEBAGAI PEMODERASI PENGARUH PROFITABILITAS , UKURAN PERUSAHAAN , KEPEMILIKAN PELAPORAN KEUANGAN THE ROLE OF AUDIT OPINION AS A MODERATOR OF THE AFFECT OF PROFITABILITY , FIRM SIZE , INSTITUTIONAL OWNERSHIP, AND AUDIT. JRAMB, Prodi Akuntansi, Fakultas Ekonomi, UMB Yogyakarta, 5(1), 1-18.

Basir, S. I., \& Muslih, M. (2019). PENGARUH FREE CASH FLOW, LEVERAGE, PROFITABILITAS DAN SALES GROWTH TERHADAP MANAJEMEN LABA. Jurnal AKSARA PUBLIC, 3(2), 104-111.

Dahar, R., Yanti, N. S. P., \& Rahmi, F. (2019). PENGARUH STRUKTUR MODAL, UKURAN PERUSAHAAN DAN RETURN ON EQUITY TERHADAP NILAI PERUSAHAAN PROPERTY AND REAL ESTATE YANG TERDAFTAR DI BURSA EFEK INDONESIA. Jurnal Ekonomi \& Bisnis Dharma Andalas, 21(1), 121-132.

Fadilla, N., \& Aryani, F. (2019). Pengaruh Free Cash Flow dan Pertumbuhan Perusahaan Terhadap Kebijakan Utang Pada Perusahaan Sektor Manufaktur yang Terdaftar di Bursa Efek Indonesia Kategori LQ 45 Tahun. Neraca : Jurnal Akuntansi Terapan, 1(1), $43-54$.

Fatimah, Mardani, R. M., \& Wahono, B. (2017). PENGARUH GOOD CORPORATE GOVERNANCE TERHADAP NILAI PERUSAHAAN DENGAN KINERJA KEUANGAN SEBAGAI VARIABEL INTERVENING (Studi Kasus Pada Perusahaan 
Manufaktur Sektor Barang Konsumsi yang Terdaftar di BEI Tahun 2015-2017). EJurnal Riset Manajemen PRODI MANAJEMEN, 51-69.

Kurniawan, D. (2008). Regresi Linier. In Statistic (pp. 1-6). Vienna, Austria: R Development Core Team (2008). R: A language and environment for statistical computing. $\mathrm{R}$ Foundation for Statistical Computing.

Lestari, E. (2018). Pengaruh Kebijakan Hutang dan Kebijakan Dividen Terhadap Kinerja Keuangan (Studi Kasus pada Perusahaan yang Go Public di Bursa Efek Indonesia). Jurnal Eksekutif, 15(2), 356-370.

Mudjijah, S., Khalid, Z., \& Astuti, D. A. S. (2019). PENGARUH KINERJA KEUANGAN DAN STRUKTUR MODAL TERHADAP NILAI PERUSAHAAN YANG DIMODERASI VARIABEL UKURAN PERUSAHAAN. Jurnal Akuntansi Dan Keuangan, 8(1), 41-56.

Muharromah, E. D., Amin, M., \& Mawardi, C. (2018). PERSEPSI MAHASISWA AKUNTANSI MENGENAI PENGARUH PREVENTING DAN NEUTRALIZATION TERHADAP KECENDERUNGAN BERPERILAKU CURANG (STUDI EMPIRIS PADA UNIVERSITAS ISLAM MALANG). E-JRA $V$, 07(04), 104-113.

Setiawati, E., Mujiyati, \& Rosit, E. M. (2019). PENGARUH FREE CASH FLOW DAN LEVERAGE TERHADAP MANAJEMEN LABA DENGAN GOOD CORPORATE GOVERNANCE SEBAGAI VARIABEL MODERASI. AKUNTABILITAS: JURNAL PENELITIAN DAN PENGEMBANGAN AKUNTANSI, 13(1), 69-82.

Setiono, D. B., Susetyo, B., \& Mubarok, A. (2017). PENGARUH PROFITABILITAS, KEPUTUSAN INVESTASI, KEBIJAKAN DIVIDEN DAN KEBIJAKAN HUTANG TERHADAP NILAI PERUSAHAAN (Studi Empiris pada Perusahaan Manufaktur Sektor Industri Barang Konsumsi yang Terdaftar di Bursa Efek Indonesia periode 2011 2015). PERMANA, VIII(2), 32-50.

Sihotang, D. R., \& Saragih, J. L. (2017). PENGARUH KEBIJAKAN DIVIDEN, KEBIJAKAN HUTANG DAN PROFITABILITAS TERHADAP NILAI PERUSAHAAN PADA PERUSAHAAN MANUFAKTUR YANG TERDAFTAR DI BURSA EFEK INDONESIA. JRAK, 3(1), 25-46.

Somantri, I., \& Sukardi, H. A. (2019). PENGARUH KEPUTUSAN INVESTASI, KEBIJAKAN HUTANG DAN KEBIJAKAN DIVIDEN TERHADAP NILAI PERUSAHAAN. JEMPER(Jurnal Ekonomi Manajemen Perbankan), 1(1), 1-10. Retrieved from http://jurnal.usbypkp.ac.id/index.php/jemper

Sulastri, A., Puspa, D. F., \& Fauziati, P. (2016). Pengaruh Leverage, Size Perusahaan Dan Kinerja Lingkungan Terhadap Kinerja Keuangan Perusahaan Yang Terdaftar Di Bursa Efek Indonesia (Bei). Jurnal Fakultas Ekonomi, 8(1), 1-11. Retrieved from http://ejurnal.bunghatta.ac.id/index.php?journal=JFEK\&page

Syamsudin, R., Afifudin, \& Junaidi. (2019). PENGARUH GOOD CORPORATE GOVERNANCE, FREE CASH FLOW DAN LEVERAGE TERHADAP KINERJA KEUANGAN PERUSAHAAN LQ45 DI BEI. E-Jra, 08(01), 1-13. 